\title{
A Research Study on the Identification, Characterization, and Gelatinase Enzyme Activities of the Halotolerant Bacteria Isolated from Salinized Sheep Skins
}

\author{
Hamdullah SEÇKINN*, Nursel DOSTBİL
}

Department of Biology, Faculty of Science, Van Yüzüncü Yıl University, Van, Turkey

\begin{abstract}
Received: 21.02 .2018
Accepted: 05.04.2018

Available online: 24.04 .2018

Published: 30.06 .2018

Abstract: This study was carried out in order to determine the production of gelatinase enzyme in isolates by isolating halophilic bacteria from saline-stored sheep skins. Accordingly, optimal temperature stability, optimum salt concentration, and plasmid-coded resistance status of the enzyme were investigated. Feed media that contain salt concentrations increasing periodically (with the rates of $5 \%, 10 \%, 15 \%, 20 \%, 25 \%$ and $30 \%$ ) to multiply bacteria isolated from sheep skins were used.

In this study, 280 strains that were isolated according to the Bergey's Manual of Determinative Bacteriology were examined. In trials of gelatinase enzyme activities, it was determined that the strains that produced positive results were Streptococcus spp. and Staphylococcus spp. and it was observed that isolates have the best ability of multiplying under the incubation conditions of $30^{\circ} \mathrm{C}$ in 3 days and that multiplication of bacteria slowed in the case of increasing salt concentration. The rates of $1 \%, 1.5 \%, 2 \%$ and 3\% gelatinase feed media were used to determine the enzyme activities and it was revealed that in media containing $1.5 \%$ gelatin produced optimal enzyme activity. Positive gelatinase activity was observed only in $2.8 \%$ of the halophilic bacteria isolated from sheep skins. Halophilic strains performing plasmid coded enzyme activity was not observed.
\end{abstract}

Keywords: Sheep skins, Halophilic bacteria, Gelatinase enzyme, Plasmid, Anti-biogram test

\section{Tuzlanmış Koyun Derilerinden İzole Edilen Halotolerant Bakterilerin Teşhisi, Karakterizasyonu ve Jelatinaz Enziminin Aktivitesinin Araştırılması}

\begin{abstract}
Özet: Bu çalışma tuzlanarak muhafaza edilmiş koyun derilerinden halofilik bakteri izolasyonu yapılarak, izolatlarda jelatinaz enzim prodüksiyonu belirlemesi amacıyla yapıldı. Buna bağlı olarak enzimin optimal sıcaklık stabilitesi, optimum tuz konsantrasyonu ve plasmid kodlu dirençlilik konumu araştırıldı. Deri örneklerinden izole edilen halofilik bakterilerin çoğaltılmasında, periyodik olarak gittikçe artan oranlarda (\% 5, \% 10, \% 15, \% 20, \% 25 ve \% 30) tuz konsantrasyonu içeren besi ortamları kullanıldı.

Çalışmada Bergey's Manuel of Determinative Bacteriology'e göre izolasyonu yapılan 280 bakteri suşu üzerinde çalışıldı. Jelatinaz enzim aktivitesi denemelerinde pozitif sonuç veren suşların Streptococcus spp. ve Staphyllococcus spp. olduğu tespit edildi ve izolatların optimal olarak \% 10 tuz konsantrasyonu içeren besi ortamında $30^{\circ} \mathrm{C}^{\prime}$ de 3 gün inkübasyon koşullarında en iyi çoğalma yeteneğine sahip olduğu, tuz konsantrasyonunun arttırılması durumunda bakteri çoğalmasının yavaşladığı gözlendi. Jelatinaz enzim aktivitesinin tanımlanmasında ise $\% 1, \% 1.5, \% 2$ ve $\% 3$ oranlarında jelatin içeren besi ortamı kullanılarak optimal enzim aktivitesinin \% 1.5 jelatin içeren besi ortamlarında olduğu tespit edilmiştir. Koyun derilerinden izole edilen halofilik bakterilerin ancak \% 2.8'inde pozitif jelatinaz aktivitesi tespit edildi. Plasmid kodlu jelatinaz enzim aktivitesi gösteren halofil suşa rastlanmamıştır.
\end{abstract}

Anahtar kelimeler: Koyun derisi, Halofilik bakteri, Jelatinaz enzimi, Plasmid, Antibiyogram testi

\section{Giriş}

Deri, canlıyı soğuğa, sıcağa, mekanik etkilere, zararlı ışınlara ve mikroorganizmalara karşı koruyan, beslenmek amacıyla hayvanların kesiminden sonra ortaya çıkan yan üründür. Geçmişte insanlar hayvanların etlerinden besin olarak yararlanmış, paleolitik çağlarda derinin mikroorganizmik faaliyetler sonucu kolayca bozulabildiğini fark etmişlerdir. Böylece deriyi işlemeye başlayarak, deri sanayisinin ortaya çıkmasını sağlamışlardır. Deri en eski giysi materyallerinden biridir. Günümüzde deri ürünlerinin insan sağlığına uygun olmaları, doğal görünümleri, prestij veya sosyal statü göstermeleri gibi nedenlerden dolayı kullanım alanı genişlemiştir. Kullanım alanının gelişmesi deri üretimini arttırmıştır (Öndoğan, Pamuk, Tama, Yaşatan, \& Akman, 2009).
Hayvanlardan yüzüldükten sonra salamura işleminden başka işlem görmemiş deriler ham deri olarak tanımlanır. Ham deri \% 60-70 oranında su ve suda çözünen, kolay parçalanabilen protein bulundurduğundan dolayı bakteri üremesi için uygun bir ortam oluşturur. Yapılan araştırmalara göre deriden sıklıkla proteolitik, lipolitik ve sakkarolitik aktiviteye sahip bakteriler izole edildiği bildirilmiş olup bu mikroorganizmalar uygun olmayan taşıma ve depolama koşullarında gelişip, deride bozulmaya neden olmaktadır (Birbir \& Ilgaz, 1996). Tuzla koruma yöntemi dericilerin çoğu tarafından tercih edilip, tuza toleransı olmayan mezofil bakterilerin gelişimini kontrol edilebilirken, halofil bakterilerin gelişimi kontrol edememektedir (Kallenberger, 1984; Bailey \& Birbir, 1993). 
Halofilik mikroorganizmaların habitatları tuzcul ortamlardır. Halofilik prokaryotlar içerisinde hem bakterilere hem de arkebakterilere ait türler bulunur. $\mathrm{Bu}$ mikroorganizmalar tuz göllerinde, tuz üretim tesislerinde ve tuzlanmış balık ve derilerin yüzeyinde bulunurlar. Hafif derecede halofiller $0.2-0.85 \mathrm{M}$ (\% $\quad-2-5)$, 1lıml halofiller $0.85-3.4 \mathrm{M}$ (\% 5- 20) ve ekstremhalofiller ise üremeleri için 3.4-5.1M (\% 20-30) NaCl konsantrasyonuna ihtiyaç duyarlar (DasSarma \& Arora, 2001; Grant, 2004). Tuzlu habitatlarda yaşayan bazı bakteriler tuzu tolere edebilirler ve halotolerant olarak adlandırılırlar.

Mudrryk ve Donderski (1982), Polonya'da Gardno Gölü'nden izole ettikleri halofilik bakterilerde metabolik aktivitesi ile ilgili çalışmalarında $\mathrm{NaCl}$ konsantrasyonun artmasıyla substrat kullanımının azaldığını belirlemişlerdir. $\quad \mathrm{Bu}$ mikroorganizmalardan biyomolekülleri tuz stresinden koruyan ajanlar, biyopolimerler, izomeraz ve hidrolaz gibi enzimler, karoten, fermente gidalar ve gida katk1 maddeleri endüstriyel yolla üretilmektedir (Rothschild \& Mancinelli, 2001; Oren, 2002, Satyanarayana, Raghukumar, \& Shivaji, 2005). Malatdehidrogenaz ve dihidroflatredüktaz, selülaz, akalinfosfataz, ekstrasllülerhidrolitik enzimler halofilik bakterilerden izole edilirler (Zusman, et al., 1989; Mevarech, Eisenberg, \& Neumann, 2000; Demirjian, Morís-Varas, \& Cassidy, 2001). Halofilik bakterilerin bazıları gıdalarda bozulmalara neden olurlar. Yüksek tuz konsantrasyonları içeren su ürünlerinin (kuru tuzlama uygulanmış veya salamura edilmiş balık) bozulmalarına zorunlu halofilik bakteriler ile gram-negatif, halofilik anaerobik veya aerobik bakteriler, ozmotolerant maya türleri neden olmaktadır (Çaklı \& Kışla, 2003). Hayvan derisi kesim sonrası \% 60-65 neme sahiptir ve derinin nem içeriği tuzlama ile \% 35-40'a kadar düşürülebilmektedir. Bu durum bakteriyel gelişimi sinurlasa da yeterli koruma sağlayamamaktadır. Yapılan araştırmalarda deniz ve göl sularının halofil bakteri içerdiği ve deri konservasyonunda buralardan elde edilen tuzların kullanılmasıyla koruma işleminin gerçekte istenildiği gibi yapılamadığı açılanmıştır (Birbir \& Ilgaz 1996; Birbir, Kalli, \& Johannson, 2002). Tuzla korunmaya çalışılan derilerde, tuza toleranslı olmayan mezofil bakterilerin kontrol altına alınabilmesine rağmen halofil bakterilerin geliştiği ve koruma işlemi esnasında deriye geçerek deri üzerinde üreyebildiği belirtilmektedir (Bailey \& Birbir, 1993). Bunun yanı sıra kullanılan tuzun çevreye olumsuz etkileri olduğu da bilinmektedir.

$\mathrm{Bu}$ çalışmadaki amacımız, deri çürümesine sebep olan jelatinaz enzimini sentezleyen bakterilerin çoğalmasını sağlayan optimal şartları ve jelatinaz enzim produksiyonu gösteren suşların plazmid kökenli olup olmadığını araştırmaktır.

\section{Materyal ve Metod}

\subsection{Materyal}

$\mathrm{Bu}$ çalışmanın materyalini Van Erçek Gölü civarındaki dericilerden toplanan, tuzlanarak muhafaza edilmiş deri örnekleri oluşturdu. Deri örnekleri gruplar halinde farklı zaman aralıklarında alındı. 18 adet tuzlanmış koyun derisinden steril eküvyon çubuğu yardımıyla bakteri örnekleri halofil karakterde sıvı besiyerine inokule edildi ve aseptik şartlarda laboratuvara getirilerek çoğalması için farklı sıcaklıklarda denemek koşuluyla etüvde inkübasyona birakıldı.

Alınan koyun derilerinde halofil karakterde halofilik özelliğe sahip başta Streptococcus spp. ve Staphyllococcus spp. suşları olmak üzere bir dizi bakteri izolatları kullanildı.

\subsection{Tuzlanmış Deri Numunelerinden Bakteri} Suşlarının İzolasyonu

1. Koyun derilerinden steril eküvyon çubuğu ile bakteri örnekleri alınarak $1 \mathrm{ml}^{\prime}$ lik Nutrientbroth'a inoküle edilmiştir. Besiyeri $30{ }^{\circ} \mathrm{C}^{\prime}$ de 3 gün süresince inkübe edilmiştir.

2. Saf halde halofilik bakteri kültürünü hazırlayabilmek amacıyla bir seri sulandırmalar yapilarak $\left(10^{-3}, 10^{-4}\right.$, $10^{-5}, 10^{-6}, 10^{-7}$ ) adi jelöz'e yayma metoduyla ekim yapılarak 3 gün süreyle inkübasyona birakılmıştır.

3. İnkübasyondan sonra, besiyerinde tek düşmüş farklı morfolojik görünüme sahip koloniler saf kültür olarak seçilmiştir.

4. Seçilen koloniler N1 agar'a çizgi şeklinde ekimi yapıldıktan sonra 3 gün süreyle etüvde inkübe edilmiştir.

5. N1 Agar'da üreyen suşların yatık agar'da stok kültürleri hazırlanmıştır.

6. İzole edilen suşlar HS1, HS2, HS3, HS4, ...... şeklinde tanımlanmıştır.

7. Yatık agardaki her saf kültür Nutrientbroth'da üretilerek jelatin hidrolizinin test edilmesi için jelatin besiyerine çizgi ekimi yapılarak inkübasyona bırakılmıştır.

8. İnkübasyon sonucunda, besiyerinde olası jelatinin hidrolizi frazier solusyonu ile test edilmiştir.

9. Jelatinaz pozitif suşların, plasmid kodlu olup olmadığını belirlemek için acridineorange'li buyyonda üretilmek üzere inkübasyona bırakılmıştır.

10. Besiyerinde üremesi tamamlanan suşların, jelatinli besiyerine çizgi şeklinde ekimi yapılmıştır.

11. Frazier solusyonu ile tekrar jelatinin hidrolizinin olup olmadığı kontrol edilmiştir.

\subsection{Disk difüzyon testi}

1. Saf olarak seçilen halofil bakteri suşları tuz konsantrasyonu ayarlanmış adi buyyon' da $30^{\circ} \mathrm{C}^{\prime}$ de 3 gün süreyle inkübasyona bırakılmıştır.

2. İnkübasyon sonunda, test suşları LB agar'a $0.1 \mathrm{ml}$ yayılmıştır. Denenecek antibiyotik diskleri belirli aralıklarla yerleştirilmiş ve 3 gün inkübasyona birakılmıştır.

3. İnkübasyon sonucunda, antibiyotik diskinin çevresindeki inhibisyon zon çapları $\mathrm{mm}$ olarak ölçülmüştür.

4. Disklerin her birinin birbiri ile aralarındaki aditif, sinerjik ve antagonist etkilerinin olup olmadığ kontrol edilmiştir.

5. Disk çevresindeki bakteri üremesi dirençlilik profilini, üremenin olmaması ise duyarlılık profilini oluşturulmuştur.

\subsection{Jelatinin hidrolizi}

Jelatinaz üretiminin tespiti bakteri identifikasyonunda önemli bir testtir. Jelatin bir hayvansal kollojen türevi olan bir proteindir. Jelatini hidrolize eden enzim jelatinaz adını alır. Jelatinaz üretimi bazı bakteriler için virülens faktörü olabilmektedir. 
$\mathrm{Bu}$ amaçla jelatin ile hazırlanmıs jeloz besiyerine batırma yöntemi ile bakterinin saf kültüründen platin iğne ile ekim yapılmış $28{ }^{\circ}{ }^{\circ} C^{\prime}$ de 3 gün süreyle inkübasyona bırakılmıştır. İnkübasyon sonucunda besiyerleri $28{ }^{\circ} \mathrm{C}$ sıvı halde olduğundan, buzdolabına konulduğunda besiyeri katılaşma göstermez ise bakteri jelatini hidrolize etmiş demektir. Katılaşma gözlenmişse haftada bir kontrol yapılarak 4 haftaya kadar bekletilir (Çetin, 1968).

\subsection{Frazier solüsyonunun hazırlanması}

Frazier solusyonu $\mathrm{HgCl}_{2}, \mathrm{HCl}$ ve distile su kompleksi olarak hazırlanıp aseptik koşullarda oda sıcaklığında 7 gün süre ile çalışmada kullanılmak üzere muhafaza edilmiştir. Çalışmada Frazier solusyonu gelatinli besiyerinde bakteri suşları üretildikten sonra test amacıyla uygulanmıştır.

\subsection{Jelatinaz enzim aktivitesinin plasmid kodlu olup olmadığının saptanması ve eleminasyon testleri}

Tuzlanarak muhafaza edilen koyun derilerinden alınan halofilik bakteri suşlarında plasmid kodlu jelatinaz enziminin belirlenmesi amacıyla şu işlemler yapılmıştır.

1. $30 \mu \mathrm{gr} / \mathrm{ml}$ gibi plasmid eliminatörü ajanla hazırlanmış 2'şer ml'lik LB buyyonlara ve plasmid eliminatörsüz LB buyyonlara bakteri suşları inokule edilerek $30{ }^{\circ} \mathrm{C}^{\prime}$ de 3 gün boyunca inkübasyona bırakılmıştır.

2. İnkübasyon sonucunda, üreyen bakteriler $10^{-2}$ sulandırma ile jelatin içeren besi ortamlarına aktarılarak enzim produksiyonu için test uygulanmıştır. Aynı şekilde 2 ml'lik $30 \mu \mathrm{gr} / \mathrm{ml}$ akridineorange'li buyyonlarda halofilik karakterdeki bakteri suşları üretilerek jelatin içeren besi ortamlarına ekimi yapılarak 3 gün süreyle 30 ${ }^{\circ} C^{\prime}$ de inkübe edilmiştir. Her iki durumda da akridineorange'li ve akridinorange'siz üretilen holafilik bakteri suşlarının jelatinaz prodüksiyonunu besi ortaminda belirlemek amaciyla frazier solusyonu ile test edilerek karşılaştırma yapılmıştır.

Yapılan test sonucunda, halofilik bakteri suşlarında jelatinaz enziminin plasmid kodlu olmadığ belirlenmiştir. Denenen halofilik bakteri suşlarınınsa jelatinaz enzim aktivitesinin farklı düzeylerde olduğu test edilmiştir.

Sonuçta jelatinaz enzim üretimi gösteren suşların farklı bakterilere ait olduğu ve jelatinaz enzim aktivitesi göstermeyen suşlarda da plasmid eliminasyonu olarak test edilmesi dirençlilik fenomeninin olup olmadığının anlaşılması için uygulanmıştır.

\subsection{Jelatinaz enziminin plasmid ile ilişkisinin saptanmasi}

Koyun derilerinden bakterilerde Jelatinaz enzimini üreten dirençlilik olayının plasmide bağlı olup olmadığının araştırılması için, dirençli örnekler sıvı besiyerlerine ekilerek inkübasyona bırakılmışlardır. 18 saat üretilen bakteriler 10-2 sulandırma ile jelatin içeren halofilik karakterdeki agar ortamına yayma yöntemiyle ekilmişlerdir.

Başlangıçta antibiyotik dirençliliği ve jelatinaz dirençliliği taşıyıp taşımadığı test edildikten sonra, dirençlilik mekanizmasının plasmid kodlu olmadığı saptanmıştır.

Alternatif yöntem olarak çizgi şeklinde ekilerek üretilen suşlardan steril toplu iğne kullanılarak jelatin içeren besi ortamına ekim yapıldıktan sonra jelatinaz produksiyonuna karşı hassasiyet aranmıştır.

\subsection{Jelatinaz prodüksiyonu ve antibiyotiğe hassas suşların izolasyonu}

Jelatinaz produksiyonuna hassas olan suşların seçilmesi için akridineorange'li halofilik buyyonlara Streptococcus spp. ve Staphyllococcu spp. suşları inoküle edilerek 3 gün $30{ }^{\circ} \mathrm{C}^{\prime}$ de inkübasyona birakılmıştır. İnkübasyon sonucunda, halofilik agarlara $10^{-2}$ sulandırma ile her suş için 2'şer örnek petriye yayma şeklinde ekim yapılıp 30 ${ }^{\circ} C^{\prime}$ de 3 gün etüvde inkübasyona bırakılmıştır. Yine inkübasyon sonucunda, jelatinaz produksiyonu pozitif ve negatif suşlarda herhangi bir değişiklik olup olmadığ1 araştırılmıştır. Aynı anda jelatinaz pozitif olan halofilik Streptococcus spp. ve Staphyllococcus spp. suşlarına antibiyotik testi uygulanarak, jelatinaz pozitif ile antibiyotik hassasiyeti arasındaki ilişki araştırılmıştır.

\section{Bulgular}

Tuzlanmış deri numunelerinde Streptococcus spp. ve Staphyllococcus spp. suşları izole edilmiştir. Tuzlanmış koyun derilerinden izole edilen halofil Streptococcus spp. ve Staphyllococcus spp. suşlarının uygulanan altı farkl1 antibiyotiklere karşı duyarlılıkları testlerinin hem dirençlilik ve hemde duyarlılık profillerinin farklılık gösterdiği belirlenmiştir (Tablo 1 ve 2). Her iki bakteri çeşidinde de dirençlilik \% de oranlar daha yüksek gözlenmiştir. Bakterinin dirençli profil sergilemesi bakteri çoğalmasının ve derideki kontaminasyonun hızını güçlendirmektedir.

Jelatinaz prodüksiyonunu plasmid eliminasyonu testleri sonucunda denenen suşlarda plasmid kodlu olmadığı bulunmuştur. Çalışma sırasında koyun derilerinden toplam 280 adet olmak üzere 221 adet Streptococcus spp. suşları ve 59 adet Staphyllococcus spp. bakteri suşları izole edilmiştir. 17 adet Streptococcus spp. suşlarında jelatinaz pozitif (\% 7.69) olduğu ve 204 (\% 92.30) suşta ise jelatinaz negatif sonuç bulunmuştur. 3 adet Staphyllococcus spp. suşlarında jelatinaz pozitif (\% 5.08) olduğu ve 56 (\% 94.91) suşta ise jelatinaz negatif sonuç bulunmuştur. Jelatinaz pozitif izolatların yapılan plasmid eliminasyon testlerinden sonra plasmid kodlu jelatinaz produksiyonuna rastlanmamıştır.

Tablo 1. Tuzlanmış koyun derilerinden ayrımı yapılan halofil Streptococcus spp. suşlarının farklı antibiyotiklere karşı duyarlılıkları

\begin{tabular}{lllllll}
\hline Antibiyotikler & Trimetazidin & Ampisilin & İmipenem & Metronidazol & Ceftazidime & Chloramhenicol \\
\hline Dirençli & $\% 92$ & $\% 76$ & $\% 72$ & $\% 97$ & $\% 67$ & $\% 64$ \\
Duyarl1 & $\% 8$ & $\% 24$ & $\% 28$ & $\% 3$ & $\% 33$ & $\% 36$ \\
\hline
\end{tabular}


Tablo 2. Tuzlanmış koyun derilerinden ayrımı yapılan halofil Staphyllococcus spp. suşlarının farklı antibiyotiklere karşı duyarlılıkları

\begin{tabular}{lllllll}
\hline Antibiyotikler & Trimetazidin & Ampisilin & İmipenem & Metronidazol & Ceftazidime & Chloramhenicol \\
\hline Dirençli & $\%$ 95 & $\% 86$ & $\% 68$ & $\% 89$ & $\% 72$ & $\% 59$ \\
Duyarl & $\% 5$ & $\% 14$ & $\% 32$ & $\% 11$ & $\% 28$ & $\% 41$ \\
\hline
\end{tabular}

\section{Tartışma ve Sonuç}

Hayvan derisinin havada, suda ve toprakta bulunan mikroorganizmaları içerdiği, canlı hayvanlarda bu mikroorganizmaların çoğunun deri üzerinde çok az etkiye sahip olduğu fakat kesim sonrasında ölü hayvandan elde edilen derinin çıkarılmasından sonra bu organizmaların gelişmek için tam bir ortam bulduğu belirtilmiştir. Özellikle hayvandan çıkarılan deri, kan ve pislikler ile bulaşmış, sıcak, ıslak ve ortamdaki mikroorganizmalarla bulaşmış durumda ise kesimden altı saat sonra bakteri üremesinin büyük boyutlara ulaştığı ve derinin yapısına önemli ölçüde zarar verdiği bundan dolayı da yeni yüzülen derilerin kesimden hemen sonra bol su ile yıkanması gerekmektedir (CastroEscarpulli, et al., 2002).

Ekstrem halofilik bakteriler \% $\quad 10-15 \quad \mathrm{NaCl}$ konsantrasyonun üzerinde çoğalırlar. Optimal çoğalmaları ise \% $20 \mathrm{NaCl}$ konsantrasyonun üzerindedir (Lanyi, 1974). Çalışmamızda tuzlanmış koyun derisinden izole edilen halofilik bakteriler $\% \quad 10-30 \quad \mathrm{NaCl}$ konsantrasyonu içeren besi ortamlarında çoğaltılarak optimal tuz konsantrasyonunun \% 10 olduğu tespit edilmiştir.

Ekstremofilik olarak siniflandirılan mikroorganizmalar; volkanların yüksek sıcaklıklarında, kutupların düşük sıcaklıklarında, çok düşük ve çok yüksek $\mathrm{pH}$ değerlerinde ( $\mathrm{pH}$ 0-3 veya $\mathrm{pH}$ 10-12 ) veya çok yüksek tuz konsantrasyonlarında (\% 5-30) yaşamak için ortama adapte olmuşlardır (Niehaus et al., 1999). Bu şekildeki ortam şartları bakımından farklı ekolojik koşullarda yaşayan mikroorganizmalar termofilik, asidofilik, alkalifilik ve halofilik bakteriler şeklinde sinıflandırılmıştır (Zeikus, 1979).

Ekstrem halofilik mikroorganizmaların özellikle tuz konsantrasyonu yüksek olan ortamlarda yaşam kalitelerinin daha zengin olduğu ve bol bulundukları, izolasyonlarında ise basit besi ortamlarında sadece ortamin tuz konsantrasyonu arttırılarak kolayca izole edilebildikleri görülmüştür. Tuzun derilerin mikroorganizma kontaminasyonuna karşı çok etkili bir koruyucu vazifesi gördüğü göz önüne alındığında tuzun koruyucu olarak kullanıldığ1 ve ekstrem halofilik mikroorganizmaların gelişmesi diğer mikroorganizmalara göre çok daha kolay olacaktır. Dolayısıyla derilerin enzim salgılayarak yer yer çürümelerle beraber parçalanmalara neden olan bu tip bozulmasında halofilik mikroorganizmalar önemli bir role sahiptir. Bu durum özellikle tuzlanmış derilerde ve deri endüstrisinde önemli ekonomik kayıplara neden olmaktadır. Halofilik mikroorganizmaların derilerde neden olduğu bu bozulmalar özellikle onların hücre dışı enzim aktiviteleri (jelatinaz, kollagenaz) ile ilgilidir. Ancak yüksek tuz konsantrasyonlarında gerçekleştirilen bazı biyoteknolojik uygulamalar için ise bu mikroorganizmaların jelatinaz ve kollagenazları büyük ilgi çekmektedir.
Halofilik bakteriler ortamdaki tuz konsantrasyonuna göre; tuza toleransli, az, orta ve kuvvetli halofilik olmak üzere çeşitli gruplara ayrılmıştır. $\mathrm{Bu}$ bakterilerin tuzsuz ortamda gelişememesi, tuza toleranslı bakterilerle aradaki en önemli farkı oluşturmaktadır (Birbir \& Ilgaz, 1996). Bu çalışma kapsaminda tuzlanmış olarak muhafaza edilen hayvan derilerinde halofilik bakterilerin varlığı kısmi jelatinaz aktiviteleri araştırılmıştır. Çalışma materyalini oluşturulan koyun derilerinden izole edilen bakterilerin üretilmesinde beş farklı ( $\% 10, \% 15, \% 20, \% 25$ ve \% 30) ve ara formlarda tuz konsantrasyonu kullanılmıştır. Bakterilerin gelişimi için en uygun tuz konsantrasyonun \% 10 olduğu, \% 10'un üzerindeki tuz konsantrasyonunda üremenin yavaşladığı, tuz içermeyen besi ortamında bakterilerin çoğalma yeteneğini kaybettikleri gözlenmiştir. Bu bulgu çalışmada kullanılan bakteri izolatlarının halofilik karakterde olduğunu göstermektedir.

Kesim esnasinda hayvan derilerinin zedelenmesi, tuzlanan derilerin kesikli bölgelerinde veya deri yüzeyinde yüzülme hatasından kaynaklanan et kalıntılarının bulunması, halofilik bakterilerin derideki kollojenimsi dokuyu jelatinaz enzimi sayesinde parçalamasına neden olmakta, zamanla deri kalitesi olumsuz yönde etkilenmektedir.

Çalışmada denenen halofilik bakteriler arasında, jelatinaz aktivitesi gösteren suşların beklenen sıklıkta olmadığı gözlenmiştir. Bu konuda muhtemelen derilerin depolama koşulları ve süresi etkili olmuştur.

Jelatinaz, lipaz, sellulaz ve beta-galaktozidaz kimya endüstrisinde, yem katkı maddesi olarak ve gida sektörü gibi farklı alanlarda kullanılmaktadır (Birbir \& Sesal, 2003). Teste tabii tutulan bakterilerin jelatini hidroliz etme yeteneği birbirinden farklı olduğu belirlenmiştir.

Çalışmada disk diffüzyon metoduyla yapılan antibiyogram testinde pozitif jelatinaz aktivitesi gösteren bakterilerin denenen antibiyotiklere karşı farklı düzeylerde duyarlılık profili gösterdikleri belirlenmiştir. En az duyarlılık Streptococcus spp. suşlarında Metronidazol ve Trimetoprimde antibiyotiklerine karşı oluşurken, Staphyllococcus spp. suşlarında ise Metronidazol ve Amphicillin antibiyotiklerine karşı gözlenmiştir.

Jelatinaz, bazı mezofil ve halofilik bakteriler tarafından salgılanan bir enzimdir. Enfeksiyon etkeni olan klinik izolatlar arasında Enterococcus'ların \% 45'inde farklı düzeylerde jelatinaz aktivitesi tespit edilmiştir (Qin, Singh, Weinstock, \& Murray, 2000). Bakterilerin jelatini hidrolize etme yeteneği genellikle jelatin tüp metoduyla test edilmektedir (Vera \& Demoff, 1974). Jelatinaz aktivitesinin belirlenmesi amacıyla yapılan çalışmalarda, Castro-Escarpull et al. (2002) genellikle \% 0.5-8'e kadar değişen oranlarda jelatin içeren besi ortamları kullanılmıştır. Bu çalışmada jelatin aktivitesinin tayininde $\% 1.5$ oranında jelatin içeren besi ortamları hazırlanmıştır. 
Özellikle koyun derisinden izole edilen halofilik bakterilerin \% 1.5 optimum jelatinaz aktivitesi gösterdiği gözlenmiştir. Besi ortamında jelatin oranının azalması veya arttırılması durumunda jelatinaz aktivitesini belirleyen zon çapında azalma gözlenirken bazılarında zon oluşmamıştır.

Çalışmada denenen halofilik bakteriler arasında, jelatinaz aktivitesi gösteren suşların beklenen sıklıkta olmadığı gözlenmiştir. Bu konuda muhtemelen derilerin depolama koşulları ve süresi etkili olmuştur.

Sonuç olarak; çalışmada tuzlanmış koyun derilerinde halofilik bakteri izolasyonu yapılarak derilerin parçalanmasına neden olan jelatinaz enziminin produksiyonu araştırılırken önemle üzerinde durulması ve dikkat edilmesi gereken hususları şu şekilde özetleyebiliriz.

Van yöresinde küçükbaş (koyun) hayvan kesimi yapılan ve halkın tüketimine sunulan et benzeri ürünlerin yanı sıra, derilerinde işlenebilirliğinin belli zaman sürecinde yapılması hemen deri işletmeciliğinde işlenebilir pozisyona sokulmaması, yörede yeterli ve etkin bir deri işletmeciliğinin olmaması, tuzlanarak muhafaza edilen koyun derilerinin yıllarca uygun olmayan depolama şartlarında bekletilmesi yani kontrollü ve yeterli olmayışı, koyun derilerin teknik personel tarafından değil de halkın doğmatik bilgileriyle yeterli tuz doygunluğunu oluşturacak ön işlemlerinin yapılmaması, koyun derilerin bilinçsiz kişiler tarafından zedelenerek yüzülmesi, yüzülmüş koyun derilerinin yeterli derecede temizlenmeden muhafaza edilmesi ve kokuşmayı sağlayacak bakterilerin üremesine olanak sağlayacak bazı şartların oluşturulması, jelatinaz enzim aktivitesi gösteren halofilik karakterde bakterilerin kontrolsüz çoğalmaları.

Yukarıda belirtilen tüm şartların oluşturulması ile birlikte ülke ekonomisine bu yolla önemli sayılabilecek kayıplar verildiği düşüncesindeyiz.

\section{Kaynaklar}

Bailey, D. G., \& Birbir, M. (1993). A Study of the Extremely Halophilic Microorganisms Found on Commercially Brine-cured Cattle Hides. JALCA, 88, 285-293.

Birbir, M., \& Ilgaz, A. (1996). Isolation and Identification of Bacteria Adversely Affecting Hide and Leather Quality. Journal of Society of Leather Technologist and Chemists, 80, 147-153.

Birbir, M., \& Sesal, C. (2003). Extremely Halophilic Bacterial Communities in Sereflikoçhisar Salt Lake in Turkey. Turk. J. Biol.TÜBİTAK, 27, 7-22.

Birbir, M., Kalli, N., \& Johannson, C. (2002). Examination of Salt Quality of Sereflikockisar Lake Used in Turkish Leather Industry. Journal of Society of Leather Technologist and Chemists, 86, 112-117.

Çaklı, Ş., \& Kışla, D. (2003). Su Ürünlerinde Mikrobiyal Kökenli Bozulmalar ve Önleme Yöntemleri E.Ü. Su Ürünleri Dergisi, 20 (1-2), 239-245.

Castro-Escarpulli, G., Figueras, M. J., Aguilera-arreola, G., Soler, L., Fernandez,-rendon, E., Aparicio, G. O., Guarro, J., ... Chacon, M. R. (2002). Characterisation of Aeromonas spp. Isolated from Frozen Fish Intended for Human Consumption in Mexico. International Journal of Food Microbiology, 84, 41-49.

Çetin, E. T., (1968). Pratik Mikrobiyoloji. İstanbul Üniversitesi. 2. Baskı. Menteş Matbaası. İstanbul.

DasSarma, S., \& Arora, P. (2001). Halophiles. Encyclopedia of Life Sciences, $1-9$.

Demirjian, D. C., Morís-Varas, F., \& Cassidy, C. S. (2001). Enzymes from extremophiles Current Opinion. Chemical Biology, 5, 144-151.

Grant W. D. (2004). Life at low water activity. Phil Trans R Soc Lond B, 359, 1249- 1267.

Kalender, D., \& Yenigül, B. (2009). Deri Örneklerindeki Cr (VI)'nın Duyar Tayinine İlişkin Voltammetrik Yöntem Geliștirilmesi. 1. International
Leather Engineering Symposium, April 29th -May 1st, Izmir, Turkey, 335

Kallenberger, E. W. (1984). Halophilic Bacteria in Brine Curing. Journal of the American. Leather Chemists Association, 79, 104-111.

Mevarech, M., Eisenberg, H., \& Neumann, E. (2000). Malate Dehydrogenase Isolated from Extremely Halophilic Bacteria of the Dead Sea. 1. Purification and Molecular Characterization. Biochemıstry, 16 (17), 1977.

Mudryk, Z., \& Donderski, W. (1991). Effect of Sodium Chloride on the Metabolic Activity of Halophilic Bacteria Isolated From the Lake. Gardno Estuary Estuaries, 14 (4), 495-496.

Niehaus, F., Bertoldo, C., Kahler, M., \& Antranikian, G. (1999). Extremophiles As a Sourche of Novel Enzymes For Industrial Application. Appl Microbiol Biotechnol, 51, 711-729.

Öndoğan, Z., Pamuk, O., Tama, D., Yaşatan, İ., \& Akman, E. Z. (2009). CAD Sistemleri Yardımıla Deri Materyalinde Yüzey Kullanım Verimliliğinin Artırılmasına Yönelik Giysi Modeli Önerilmesi, Hammadde Olarak Deri Materyalinden ve Dokuma Kumaştan Gömlek Üretim Sürecinin Karşılaştırılmasına Yönelik Bir Çalışma. 1. International Leather Engineering Symposium, April 29th May 1st, 2009, İzmir, Turkey.

Oren, A. (2002). Halophilic Microorganisms and their Environments (Cellular Origin, Life in Extreme Habitats and Astrobiology). Springer, 1 edition, August 31, 600 pages

Qın, X., Singh, K. V., Weinstock, G. M., \& Murray, B. E. (2000). Effects of Enterococcus faecalis fsr Genes on Production of Gelatinase and a Serine Protease and Virulance. Infection and Immunity, 68, 2579-2586.

Rothschild, L. J., \& Mancinelli, R. L. (2001). Life in extreme environments. Nature, 409, 1092-1101.

Satyanarayana, T., Raghukumar, C., \& Shivaji, S. (2005). Extremophilic microbes: Diversity and perspectives. Current Science, 89, 78-90.

Vera, H. D., \& Demoff M. (1974). Culture media, p. 881-929. In E. H Lennette, E. H. Spaulding, and J. P. Truant (ed.), Manual of clinical microbiology, 2nd ed. American Society for Microbiology, Washington, D.C.

Zeikus, J.G. (1979). Thermophilic bacteria: ecology, physiology and technology. Enzyme Microb Technol, 1, 243-252.

Zusman, T., Rosenshine, I., Boehm, G., Jaenicke, R., Leskiw, B., \& Mevarech, M. (1989). Dihydrofolate reductase of the extremely halophilic archaebacterium Halobacterium volcanii. The Journal of Biological Chemistry, 264 (32), 18878-18883. 